\title{
Impact of Budgeting Process on Organizational Effectiveness: Evidence from Wolaita Zone Selected Woreda Public Finance Sectors
}

\author{
Amen Diakon Debebe \\ MA in Development Management), Lecturer at Wolaita Sodo University \\ Getachewu Petros Osebo \\ MSC in Economics, Lecturer at Wolaita Sodo University
}

\begin{abstract}
1.1 Abstract
The main purpose of this study was to investigate the Impact of budgeting process on the organizational effectiveness in Wolaita zone public finance and economy development sectors. Qualitative and quantitative research methods were employed. The study was carried out in purposively selected five woreda of the zone. Moreover, Stratified and simple random sampling techniques were respectively applied to select a sample of 157 staff members. From these 157 respondents, only 151 samples were used to collect the data (i.e. $96 \%$ ) of the respondents participated in the study. The data were collected through questionnaires and document analysis. The data obtained from respondents were analyzed using descriptive statistics and multiple linear regression analysis via SPSS version 20.0 soft ware. The findings of the study indicated that there was a direct relation between the effects of BPL, BI, BC, and TRB with the organizational effectiveness on WZOFED. The study indicated that the contribution of budget planning for the success of organizational effectiveness seems not promising as others did. Thus, its significance was not as strong as others. Inefficient budget utilization and Budget control in their organizations was not promising as expected. All of four independent variables are making $63.20 \%$ of the contribution to OE in WZOEFD. Finally, recommendations such as empowering major stakeholders in budget planning, improving the execution of budget implementation, establishing budget control system and Providing Training Programs for Employees to Improve Organizational Effectiveness in Finance Sectors, enhancing organizational capacity in the budget process were forwarded to overcome organizational effectiveness challenges in the study area.
\end{abstract}

1.2. Key words: Impact, budget, budgeting process, Government Finance, organizational effectiveness. DOI: $10.7176 / J E S D / 10-1-01$

\subsection{BACKGROUND OF THE STUDY}

Joshi (2003) budgeting process and performance evaluation practices in a developing country and found out that most of the organizations prepare long range plans and operating budgets, and use budget variances to measure organizations performance, for timely recognition of problems, and to improve the next period's budget.

This is also why a basic understanding of the procedures and timelines in preparing the budget at federal level is important in order to understand the budget process at regional and Woreda level. Furthermore, budgets define "use" and "purpose". The purpose or objective of a budget is related to the intended outputs. This means all budget items are related to the planned activities on which the public funds are spent and the purpose of the spending. Currently, the annual budget formulation process has two dimensions which include the identification of priorities and goals, and allocation and management of funds (MOFED, 2009).

Kariuki (2010), budgeting is a process of planning the organizational operations for its effectiveness. It is also as a management tool helps to organize and formulize management's budget planning process for organizational goal achievement and financial tool is useful for both evaluation and control of organizations for the planning of future activities. Those all are why an efficient programmed budgetary systems has a positive effect on the ability of the budgeting process to anticipate and respond with expressed measures to opportunities and pressures from the environment in which the organizations operates. In the study area most of the time stakeholders particularly budget user sectors blame and show dissatisfaction about the budget shortage. Hence, the ultimate target of this study is identifying the major factors that Impacts the budgeting process on organizational effectiveness in Wolaita zone selected public finance sectors.

\subsection{STATEMENT OF THE PROBLEM}

In developing countries, it has become increasingly complex to manage public expenditure allocation because the roles of the government have been expanded and financial resources are in scarce supply to meet this everincreasing social needs and population growth. Due to inadequate financial resources as opposed to an increasing demand for public service, there is a need to improve resource allocation through proper economic policy and expenditure planning (Getachew, 2015). 
Shields (2006) revealed that there is use of budgets mostly to implement short-term operational plans and the majority of the long- term plans being implemented before having planned budget in certain organization.

Baulmer (2012) assessed the effect of poor budgetary control practices on budget implementation and goal achievement of government owned firms. Findings exposed that there exist poor controlling practices using government owned firms, and budgetary implementation with that of organizational goal achievement are not matching or consistent by those firms.

As information obtained from the observation of different public conferences, annual review meetings, and evaluation and supervision reports, budget implementation in the study area seems to be less successfully performed. Stakeholders usually blame budget fairness and accessibility.

The previous researchers empirical reviewed studies that the effect of budget processing on organizational effectiveness affected by budget preparation, utilization and controlling. In this study a researcher attempted in depth to identify the effect of budgeting process on organizational effectiveness affected by the factors like budgets planning, budgets preparation, budget implementation, and budget controlling in the selected Wolaita zone public finance and Economic Development offices (WOFED). Therefore, the researcher tried in depth to fill the gaps not considered in the previously done researchers' findings by using different variables in the study.

\subsection{RESEARCH OBJECTIVES:}

The overall objective of the study is to examine the Impact of budgeting process on organizational effectiveness in study areas public finance sectors.

The Specific objectives of this study are the followings:

$>$ To examine the importance of budget planning on organizational effectiveness.

$>$ To determine the impact level of budget preparation with the organizational effectiveness.

$>$ To identify factors affecting budget implementation on organizational effectiveness.

$>$ To investigate the impact of budget controlling on organizational effectiveness.

\subsection{REVIEW OF RELATED LITERATURE:}

\subsubsection{Theoretical and conceptual literature review}

Budgets were first presented in the 1920 s as a tool to manage costs and cash flows in big industrial organizations according to (Bartle, 2001). The appearance of scientific management philosophy however laid emphasis on detailed information as a basis for taking conclusions thus leading to great development of management accounting and budgeting systems (Bartle, 2008). At early stage of development, budgeting was concerned with preparing and presenting reliable information to legitimize accountability and to permit correct performance evaluation and consequently, rewards (Hindereth, 2002) however, over the years, the function and focus of budgeting has shifted considerably as business organization became more complex and their environment become active.

Bartle, (2008) explanation shows that budgets today provide a focus for the organization, encouragement in the coordination of activities and facilitates control that both management level and operation level looks at the future and lays down what has to be achieved. The theoretical framework gave a motivation for development of budget concept, and highlight the development of the budget concept from a tool of directing actions within an organization to a more complex managerial tool that, managers would use to provide attention for organizations, set goals and undertake performance evaluations controlling activity and his framework provides a basic perspective through which the researcher watched budgetary controls as tool for influencing organizational effectiveness or achievement of goal.

\subsubsection{The Theory of Budgeting}

Hirst, (1987) explains that an effective budgetary control solves an organization's need to plan and consider how to confront future potential risks and opportunities by establishing an efficient system of control and similarly, Shields and Young (1993) define the theory of budgeting as a detector of variances between organizational objectives and performance budgets are considered to be the core element of an efficient control process and consequently vital part to the umbrella concept of an effective budgetary control.

\subsubsection{Theories of Public Expenditures}

As revealed by Schiavo Campo and Tommasi (1999) achieving government policy objectives, including reducing the poverty rate, can be accomplished through a variety of instruments, such as direct government spending (budget), indirect government spending (tax expenditures, contingent liabilities, loans, etc.), tax policy, regulations, and direct command. However, direct government spending is the most important instrument, and the government budget is the financial mirror of most government policies.

\subsubsection{Definition of Budget and Budgeting Process}

Budgeting is a systematic way of allocating resources: various types of government budgeting systems have been developed to serve multiple purposes, including financial control, management planning, priority setting for careful funds and accountability in the use of public resources (Hager et al,2001). 
According to Jesse (1965) the word budget is a French word, used to mean the "money bag". The word budget comes into usage to mean the public pursue, which served as a term for revenue and expenditure for the state.

Budget is both a plan as well as a control devise. It should be related were every possible to physical unites of output, setting standards of efficiency for each part of the administration and providing means of giving achievement (Nice, 2002). On the other hand, budget is the detailed plan, expressed in quantitative terms, that specifies how resources will be acquired and used during the specified period of time including planning, facilitation, communication and coordination, allocating resources, controlling the operational activities and evaluation of performance i.e. comparing actual results with budget results (Premchand, 1995).

Budgetary Systems

Budgetary systems refer to the budgeting approaches that have been adopted by various organizations to achieve various organizational goals. C. Adams et al (2003) discuss them as follows:

\section{(a)Planning, Programming and Budgeting System:}

According to Horngren, C.T (1999)., it involves the programmed plans that focus on the end objective and the gross categories of output and it is overall goals and objectives are established first, followed by identification of programs necessary to achieve the desired objectives and expected benefits. All programs to be disappeared are ranked and choice the least cost program to accomplish, "the program with lower cost will be undertaken."

(b)Value based Budgeting: This is a formal and organized approach for handling the creation of stockholders value over time and all expenditure plans are evaluated as development appraisals and that assessed in terms of the shareholders' value they will create. This helps to joining Policy and stockholder value to planning and budgeting.

\section{(c)Zero Based Budgeting:}

Agreeing to Lucey, (2002), zero based budgeting is also called priority based budgeting and it requires that all activities are reasonable and prioritized before decisions are taken relating to the amount of resources assigned to each activity. Zero based budget being complied as if the programmers were being launched for the first time on the basis of cost benefit analysis. Consequently, the budget from each cost centre should be made from zero.

(d) Activity Based Budgeting (ABB)

According the $\mathrm{C}$. Adams et al (2003) activity based budgeting (ABB) is related to activity based costing (ABC) and activity based management (ABM) .It also actually involves planning and controlling along the lines of value adding activities and processes

\subsubsection{Theory of Budgetary Control}

Suitable control is very essential to every organization be it individual or government owned all over the world and this is because if there is no adequate control of resources in the organization, it will be basically impossible to appropriate budgets and accounting practices becomes a waste. The theory of control identifies the obligations of government industries in providing social and basic services to the citizens. It indicates that administration owned industries is a basic principle of control on those rare resources they are intended to achieve. As Shields and Young (2009) oppose that government industries ought to provide both resources and employment to the citizens for meeting the laid down objectives and this implies that the government, and staff have joint responsibility to ensure proper accounting practices and timely budgetary implementation and appropriations by building effective management controls and directions. These theories are expected to live Wolaita zone government to its responsibility for standards, adequate controlling mechanism and acceptable accounting practices.

\subsubsection{Empirical literature over view}

L.M.D. Silva and Ariyarathna (2012) budgetary Process and Organizational Performance of Apparel Industry in Sri Lanka have shown strongly positive relationship. Selection techniques and regression analysis were employed in investigating the relationship between the budgetary process and organizational effectiveness.

A well designed and implemented financial organization is expected to contribute positively to the creation of a firms' value (Padachi, 2006) and high presentation reflects management effectiveness and efficiency in making use of firm's resources and this in turn contributes to the country's economy at large (Naser\&Mokhtar, 2004).Furthermore, Nyageng'o (2014) carried out a study to identify factors to effective budget implementation among local authorities in Kenya.

The results of the study discovered that effective budgetary control improved performance of local government organizations. Serem, (2013) established that there is a weak positive effect of budgetary control on performance of Non-Governmental Organizations in Kenya measured by R square at 14.3\%. Mwaura (2010) concluded that budgetary participation affects return on capital employed, return on assets to a great extent.

\subsection{RESEARCH METHEODOLOGY}

The study adopted both qualitative and quantitative survey design as it aims at collecting information from respondents on effect of budgeting process on organizational goal achievement in Wolaita zone public finance organization. Moreover, purposive sampling technique was employed by researcher because believes that these 
sectors likely have sufficient information and exposure on the topic under study. Out of the total 262 respondents, 157 sample respondents were selected.

\subsubsection{Model Specification and OLS Assumption}

The characteristics of model and the proposed variables in this study were evaluated for the fulfillment of the classical linear assumption (CLRM) (Gujarata, 2004) similarly;

According to(Ponsian, 2014) Ordinary Least Squares (OLS) regression model was used:

$\mathrm{Y}=\beta_{0}+\beta_{1} \mathrm{X} 1+\beta_{2} \mathrm{X} 2+\beta_{3} \mathrm{X} 3 \ldots \beta_{6 \mathrm{X} 6}+\varepsilon$

$$
\text { .............. }
$$

$\mathrm{OE}=\beta 0+\beta 1(\mathrm{BPl})+\beta 2(\mathrm{BPr})+\beta 3(\mathrm{BI})+\beta 4(\mathrm{BCo})+\beta 6(\mathrm{TRB})+\varepsilon$.

Where: $0=$ Intercept of the equation and $1,2 \ldots 6=$ Coefficients and $\varepsilon=$ Error term. The regression model presented the dependent variable (organizational effectiveness) and independent variables on the budgeting process were expressed as in the equation below:

$\mathrm{OE}=$ organization effectiveness, $\beta_{0}=$ intercept $\beta 1-\beta 5=$ is Coefficient of independent variables. $\varepsilon=$ errorterm.

$\mathrm{BPl}=$ budget planning, $\mathrm{Bpr}=$ budget preparation, $\mathrm{BI}=$ budget implementation, $\mathrm{BCo}=$ budgetary control and, $\mathrm{BTR}$ =budgetary tax revenue budget.

Normality: the normality assumption is required in order to conduct single or joint hypothesis test about the model parameter (Bera and jarque, 1981).

Multi Collinerity: The existence of strong correlation between the independent variables was tested using Variance Inflation Factor (VIF).In the construction of an econometric model; it may happen that two or more variables giving rise to the same pieces of information are included.

Heteroscedasticity: Another important assumption of classical linear regression model is equal variance with the error terms but, sometimes this assumption neither may not biased result to be consistently validated as result of outlier and omissions of relevant variables in the model. To check for Heteroscedasticity, BreuschPagan/Cook-Weisberg test of Heteroscedasticity, carried out.

Autocorrelation test: this is an assumption that the errors are linearity independent of one another it would be stated that they are auto correlated to test for the existence of auto correlated or not the popular Durbin Watson test was employed.

\subsection{DATA ANALYSIS AND DISCUSSION}

In conducting the study, 157 questionnaires were distributed out of which 151 were returned and answered. With response rate of $96 \%$ and $6(4 \%)$ was not returned.

1.8.1. Budget Panning

Table 1: Mean and Standard Deviation of Budget Planning

\begin{tabular}{|c|c|c|c|}
\hline Items & $\mathrm{N}$ & Mean & $\begin{array}{l}\text { Std. } \\
\text { Deviation }\end{array}$ \\
\hline $\begin{array}{l}\text { Top managements communicate the budget plan to those preparing the budget plan and } \\
\text { this helps in reduction of wastage of resources. }\end{array}$ & 151 & 3.89 & .572 \\
\hline The organization has a long term and short term budget plans & 151 & 3.87 & .797 \\
\hline Organizational departments prepare budget plans prior to the budget year. & 151 & 4.19 & .846 \\
\hline Past data is used as the starting point for producing the budgets & 151 & 4.30 & .800 \\
\hline The budgets have clear goals and objectives & 151 & 3.85 & .854 \\
\hline $\begin{array}{l}\text { When budgeting, outcomes, goals and objectives are linked to programs and } \\
\text { organizational activities. }\end{array}$ & 151 & 3.85 & .640 \\
\hline The organization put priorities for the coming annual budget conference and Committees & 151 & 3.83 & .651 \\
\hline Average & 151 & 3.9678 & .43399 \\
\hline
\end{tabular}

Source: Field survey (2018) 


\subsubsection{Budget Preparation}

Table 2: Mean and Standard Deviation of Budget Preparation

\begin{tabular}{|l|l|l|l|}
\hline \multicolumn{1}{|c|}{ Items } & N & Mean & $\begin{array}{c}\text { Std. } \\
\text { Deviation }\end{array}$ \\
\hline You have adequate understanding to prepare plan and budget. & 151 & 3.96 & .682 \\
\hline Budget is prepared based on reliable data and estimates & 151 & 4.11 & .796 \\
\hline Finance offices circulate call letter and budget guideline to all sectors on time & 151 & 4.08 & .779 \\
\hline $\begin{array}{l}\text { Your office has adequate number of professionals (budget officers) who prepare plan and } \\
\text { budget }\end{array}$ & 151 & 4.01 & .852 \\
\hline Your office revises its plan frequently in relation to budget. & 151 & 3.89 & .788 \\
\hline $\begin{array}{l}\text { In your organization expenditure budgets are planned in clear way. } \\
\text { Your office has an interest to request budget without plan }\end{array}$ & 151 & 3.91 & .816 \\
\hline Budgets are planned according to your organizational goal and Objectives. & 151 & 3.64 & .956 \\
\hline Average & 151 & 4.04 & .824 \\
\hline
\end{tabular}

Source: Field survey (2018)

1.8.3. Budget Implementation

Table 3: Mean and Standard Deviation of Budgetary Implementation

\begin{tabular}{|c|c|c|c|}
\hline Items & $\mathrm{N}$ & Mean & $\begin{array}{l}\text { Std. } \\
\text { Deviation }\end{array}$ \\
\hline You are involved in your department budget implementing for budgetary Performance. & 151 & 3.91 & .721 \\
\hline Your office utilizes the approved budget based on its plan. & 151 & 3.97 & .706 \\
\hline Your office's actual budget implementation and its reports are consistent with plan. & 151 & 4.01 & .627 \\
\hline Payment is implemented based on full documents and evidences. & 151 & 3.87 & .686 \\
\hline $\begin{array}{l}\text { Your office keeps its budget implementation in accordance with the Government } \\
\text { financial rules and regulations }\end{array}$ & 151 & 4.25 & .757 \\
\hline Average & 151 & 4.0013 & .4166 \\
\hline
\end{tabular}

Source: Field survey (2018)

1.8.4. Budgetary Control

A budgetary control is a method of controlling costs through preparation of budgets according to Drury (1996) defined budgetary control as the establishment of budgets relating to the responsibility of executives of a policy and the continuous comparison of the actual with the budgeted results, either to ensure by individual action the objective of the policy

Table 4: Mean and Standard Deviation of Budgetary Control

\begin{tabular}{|c|c|c|c|}
\hline Items & $\mathrm{N}$ & Mean & $\begin{array}{c}\text { Std. } \\
\text { Deviation }\end{array}$ \\
\hline $\begin{array}{l}\text { Your office has the practice of regular follow up program on its budget Planning and } \\
\text { control. }\end{array}$ & 151 & 4.03 & .795 \\
\hline $\begin{array}{l}\text { Budgeting control enables the organization to achieve its targets much easily since it } \\
\text { helps in aligning the actual results to the plan }\end{array}$ & 151 & 3.82 & .825 \\
\hline $\begin{array}{l}\text { The management control practice in the organization helps in linking the strategic } \\
\text { planning and operational control }\end{array}$ & 151 & 3.70 & .773 \\
\hline Your office experts have adequate capacity to evaluate budget with organization goal. & 151 & 3.93 & .830 \\
\hline Your office has strong budget control Mechanism. & 151 & 3.89 & 1.014 \\
\hline The current budget utilization and control of your office is sufficient. & 151 & 3.81 & .769 \\
\hline Your office has strong and effective Internal auditing systems. & 151 & 4.03 & .867 \\
\hline Average & 151 & 3.8903 & .52202 \\
\hline
\end{tabular}

Source: Field survey (2018) 


\subsubsection{Organizational Effectiveness}

Table 5: Mean and Standard Deviation of Organizational Effectiveness

\begin{tabular}{|l|l|l|l|}
\hline \multicolumn{1}{|c|}{ Items } & \multicolumn{1}{|c|}{ N } & Mean & $\begin{array}{c}\text { Std. } \\
\text { Deviation }\end{array}$ \\
\hline Your office faces budget shortages during the budget year. & 151 & 3.89 & .865 \\
\hline Clear awareness between budget plan and organizational goal. & 151 & 3.85 & .671 \\
\hline The expenditure budget is consistent with its organizational goal achievement. & 151 & 3.86 & .721 \\
\hline Your organization gives attention to Organizational goal achievement. & 151 & 4.04 & .599 \\
\hline Budget plan is consistent with your organizational goal achievement. & 151 & 3.95 & .677 \\
\hline Average & 151 & 3.9192 & .47507 \\
\hline
\end{tabular}

Source: Field survey (2018)

\subsubsection{Pearson Correlation analysis}

Correlation analysis was used to measure the strength and the relation between independent variables (planning, preparation, implementation, controlling, and tax revenues budgets) and dependent variable. It establishes the relative significance of each variable on organizational effectiveness. Correlation coefficient, $r$, can be a range of value from +1 to -1 . A value of 0 indicates that there is no association between two variables. A value greater than 0 indicates a positive association as one variable increases so does other. A value less than 0 indicate negative association as the value of one variable increases the value of other variable decreases.

\section{Table 6: Correlation between Budget process and Organizational Effectiveness}

\begin{tabular}{|c|c|c|}
\hline Items & Pearson correlation & Organizational Effectiveness \\
\hline \multirow{3}{*}{$\begin{array}{l}\text { CBP } \\
1\end{array}$} & ${ }^{*}$ & $.618^{* *}$ \\
\hline & Sig. (1-tailed) & .000 \\
\hline & $\mathrm{N}$ & 151 \\
\hline \multirow[t]{3}{*}{ CBPR } & Pearson Correlation & $.703^{* *}$ \\
\hline & Sig. (1-tailed) & .000 \\
\hline & $\mathrm{N}$ & 151 \\
\hline \multirow[t]{3}{*}{$\mathrm{CBI}$} & Pearson Correlation & $.623^{* *}$ \\
\hline & Sig. (1-tailed) & .000 \\
\hline & $\mathrm{N}$ & 151 \\
\hline \multirow[t]{3}{*}{$\mathrm{CBC}$} & Pearson Correlation & $.700^{* *}$ \\
\hline & Sig. (1-tailed) & .000 \\
\hline & $\mathrm{N}$ & 151 \\
\hline \multirow[t]{3}{*}{ CTRB } & Pearson Correlation & $.727^{* *}$ \\
\hline & Sig. (1-tailed) & .000 \\
\hline & $\mathrm{N}$ & 151 \\
\hline
\end{tabular}

**. Correlation is significant at the 0.05 level (1-tailed).

Source: Field survey (2018)

In table 6 results indicate that, as it has been revealed in the correlation table about the relationship between dependent variable among the independent variables, there is statistically positive and significant relationship between budget planning and organizational effectiveness $(\mathrm{r}=.618, \mathrm{p}<0.05)$. Budgetary preparation and organizational effectiveness has statistical insignificant relationship with $(\mathrm{r}=.703, \mathrm{P}>0.05)$. Budgetary implementation and organizational effectiveness has statistical positive and significant relationship at $(\mathrm{r}=.623, \mathrm{P}$ $<0.05$ ). Budgetary control and organizational effectiveness has statistical positive and significant relationship with $(\mathrm{r}=.700, \mathrm{p}<0.05)$, Tax Revenue budget and organizational effectiveness has statistical positive and significant relationship with a value of $(\mathrm{r}=.727, \mathrm{p}<0.05)$.

The findings on table 4.9 above further indicates that the highest significant relationship is seen betweenTax Revenue Budget, budget controlling, budget implementation and budget planning respectively had positive and significant relations with organizational effectiveness. The highest significant value Tax Revenue Budget, of ( $\mathrm{r}$ $=.727, \mathrm{p}<0.05)$, however, the lowest statistically significant relationship is found between budgeting planning and organizational effectiveness $(\mathrm{r}=.618, \mathrm{P}<0.05)$. 
$\mathrm{Yi}=\beta 0+\beta 1 \mathrm{X} 1+\beta 2 \mathrm{X} 2+\beta 3 \mathrm{X} 3+\beta 4 \mathrm{X} 4+\beta 5 \mathrm{X} 4+\beta 6 \mathrm{X} 6+\ldots .$. Equation 1

$\mathrm{Y}=0.356+.089+.52+.148+.264+.379+$. Equation 2

Table 7: Model Summary

\begin{tabular}{|l|c|r|r|r|r|}
\hline Model & R & R Square & Adjusted R Square & Std. Error of the Estimate & Durbin-Watson \\
\hline 1 & $.802^{\mathrm{a}}$ & .644 & .632 & .2884 & 1.838 \\
\hline
\end{tabular}

Source: Field survey (2018)

\subsubsection{Independent variables in Regression Models}

Multiple regression analysis was employees to examine the effect of Budgeting process (Budget planning, budget preparation, Budget Implementation, Budget Control, and Tax Revenue Budget) and Organizational Effectiveness.

From the regression analysis in the results in the table below, the multiple linear regression models finally appear as $\mathrm{Y}=.356+0.089 \mathrm{BPL}+0.052 \mathrm{BPR}+0.148 \mathrm{BI}+0.264 \mathrm{BC}+0.379 \mathrm{TRB}$

Where, $\mathrm{BPL}=$ Budget planning, $\mathrm{BPR}=$ Budget preparation, $\mathrm{BI}=$ Budget implementation,

$\mathrm{BC}=$ Budget controlling, $\mathrm{TRB}=$ tax revenues budget

Table 8: Regression Analysis

Coefficients $^{\mathrm{a}}$

\begin{tabular}{|l|c|c|c|c|c|c|c|}
\hline \multirow{2}{*}{ Model } & \multicolumn{2}{|c|}{ Un standardized Coefficients } & Standardized Coefficients & & & \multicolumn{3}{|c|}{ Collinearity Statistics } \\
\cline { 2 - 4 } & $\mathrm{B}$ & Std. Error & Beta & $\mathrm{T}$ & Sig. & Tolerance & VIF \\
\hline 1 (Constant) & .356 & .245 & & 1.453 & .149 & & \\
CBP & .098 & .083 & .089 & 1.177 & .000 & .427 & 2.340 \\
CBPR & .051 & .099 & .052 & .518 & .605 & .244 & 4.106 \\
CBI & .168 & .089 & .148 & 1.896 & .040 & .405 & 2.470 \\
CBC & .240 & .073 & .264 & 3.283 & .000 & .380 & 2.630 \\
CTRB & .344 & .069 & .379 & 5.017 & .000 & .431 & 2.319 \\
\hline
\end{tabular}

a. Dependent Variable: COE

Source: SPSS Output, 2018.

Multiple regression where employed to investigate the effect of budget planning, budget preparation, budget implementation, budget controlling and tax revenues budget to predict level of organizational effectiveness. The correlation between the predictor variables included in the study was examined. All predictor variables were statistically correlated with organizational effectiveness which indicates that the data was suitably correlated with dependent variable (organizational effectiveness) for examination through multiple linear regressions.

In the above, all predictor variables were statistically significant withp $<0.05(\beta 1=0.098, p=0.000),(\beta 2=$ $0.051, p=0.065),(\beta 3=0.168, p=0.040),(\beta 4=.240, p=0.000),(\beta 5=0.344, p=0.000)$. The results were confirmed the expected sign of hypothesis for all predictors variable, expect the budget preparation insignificant. Table 9: Model Summary

\begin{tabular}{|c|c|c|c|c|c|c|c|c|c|c|}
\hline \multirow[b]{2}{*}{ Model } & \multirow[b]{2}{*}{$\mathrm{R}$} & \multirow[b]{2}{*}{$\begin{array}{l}\mathrm{R} \\
\text { Square }\end{array}$} & \multirow[b]{2}{*}{$\begin{array}{l}\text { Adjusted } \\
\text { Square }\end{array}$} & & \multirow[b]{2}{*}{$\begin{array}{l}\text { Std. Error of the } \\
\text { Estimate }\end{array}$} & \multicolumn{5}{|c|}{ Change Statistics } \\
\hline & & & & & & $\begin{array}{|ll|}\mathrm{R} & \text { Square } \\
\text { Change } & \end{array}$ & $\begin{array}{l}\text { F } \\
\text { Change }\end{array}$ & df1 & df2 & $\begin{array}{l}\text { Sig. } \\
\text { Change }\end{array}$ \\
\hline 1 & $.802^{\mathrm{a}}$ & .644 & .632 & & .28837 & .644 & 52.420 & 5 & 145 & .000 \\
\hline
\end{tabular}

a. Predictors: budgeting process (Constant), CTRB, CBI, CBC, CBPR CBP,

Analysis in table above shows that the coefficient of determination (the percentage variation in the dependant variable being explained by the changes in the independent variables)

$\mathrm{R} 2=63.2 \%$ of the total variation in the organization effectiveness is explained the change in planning, preparation, implementation, controlling, and tax revenues budget while $37.8 \%$ remains unexplained. According to Signh (2007), an adjusted R squares of the above $75 \%$ is very good, between $25-50 \%$ is faire and below $25 \%$ is poor and in the given case. Therefore, the adjusted $\mathrm{R}$ square is $63.2 \%$ which is the range of good. 
Table 10: Anova

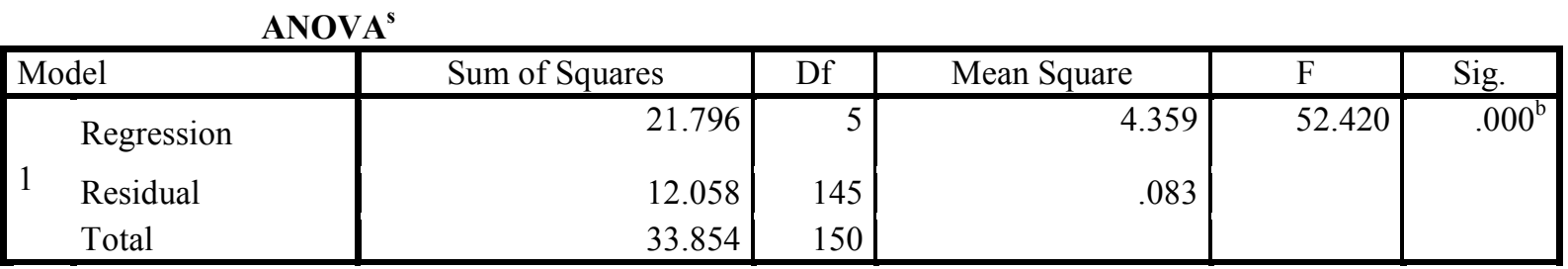

a. Dependent Variable: COE

b. Predictors: (Constant), CTRB, CBI, CBC, CBP, CBPR

The (ANOVAs model), these variables collectively, were good explanatory variables of the OE and beside this, F statistics (52.420). ANOVAs model are used to measure the overall test of significance of the models. In testing the significance level, the statistical significance was considered significant if the $\mathrm{P}$ value was less or equal to 0.05 . The significance of the regression model is as presented table above with $\mathrm{P}$ value of 0.0 which is less than 0.05 . This indicates that the regression model is strong statistically significant in predicting factors affecting organizational effeteness in budgeting processes in Hadiya zone government public finance. Basing the confidence levelat $95 \%$ the analysis indicates high reliability of the results obtained.

Table 4.14 Summary of Hypothesis Testing Results

\begin{tabular}{|c|c|c|}
\hline Cod & Hypothesis & Test Result/Relation \\
\hline 1 & Budget planning has effect on Organizational Effectiveness & Positive/significant \\
\hline 2 & Budget preparation have effect on Organizational Effectiveness & Positive/insignificant \\
\hline 3 & Budget implementation have effect on Organizational Effectiveness & Positive /significant \\
\hline 4 & Budget control have effect on Organizational Effectiveness & Positive /significant \\
\hline & Tax Revenue Budget has effect on Organizational Effectiveness & Positive/significant \\
\hline
\end{tabular}

Source: Field survey (2018)

\section{9: CONCLUSION}

Based on the above major findings of the study, the following conclusions were drawn:

Due to its important role it plays to the overall budgeting process in finance sectors is the major mechanism to ensure sound public sectors' good governance. The existence of effectiveness of organization in the office links with improves organizational efficiency and effectiveness, reduce wastage of resource, reduce information asymmetry during budget decision making, and ensures the internal reliability of financial reporting process. The organizational effectiveness of the public finance and economy development sectors office when there were more effective budget planning, budget implementations, budget controlling and tax revenues budget in the offices. The regression analysis shown in the table shows a very strong contribution of the variable to the organizational effectiveness.

This study finds that the composite measure of the budgetary planning, budgetary implementation, budgetary control and BTR for63.20\% $\left(\mathrm{R}^{2}=0.632\right)$ variance for the OE in identifying activities and added contributions to the public finance sector. That means, the impact of these four independent variables contributed for the dependent variable OE were $63.2 \%$, and the remaining $36.80 \%$ were other variables that are not included in this study. The findings of the study concluded that the magnitude of coefficients of the independent variables denoted the strength of the influence that they have on the dependent variables.

The results indicated that organizational effectiveness was measured by its independent variables which are strongly influenced by Budget planning (.098) Budget tax revenues (0.344), budgetary implementation (0.168) Budgetary controlling (0.240).

The findings Indicates that budgetary procedures are an important aspect of an organization's budgetary system because they promote more positive attitudes and behaviors on the part of managers, and employers with budget responsibility, which ultimately will enable the organization to better accomplish its goals and objectives.

Moreover, multiple regression result further shows that researcher found out that not all of the budgeting process dimensions have positive effects on organizational effectiveness budget planning; budgetary control and tax revenue budget have positive and significant effects on knowledge, skills and attitudes. However budget preparation, budgetary implementation has positive and insignificant effects on organizational effectiveness. The finding further indicates that insignificant less important on organizational effectiveness.

Finally, concluding the whole research conducted it is found that budgeting process are highly effective organizational effectiveness which should be planned, systematic and implemented by public organization to run a cycle of increasing skills in employees to increase performance based on organizational effectiveness and this further result as organization productivity growth and performance. 


\subsection{0: RECOMMENDATIONS}

Based on the findings of the study the following recommendations were forwarded:

\section{Empowering Major Stakeholders in Budget Planning}

Budget planning is starting and the corner stone in finance sectors. Without appropriate budget planning controlling and lastly decision making becomes much difficult and remains a futile attempt in overall activities in the finance sectors. The study indicated that the contribution of budget planning for the success of organizational effectiveness seems not promising as others did. Thus, its significance was not as strong as others. Moreover, empowering key stakeholders enable to become accountable and responsible for the poor performance in their sectors.

$>$ Improving the execution of budget implementation

Resources are scarce to run our daily routine functions in the firms. To cope up this limitations wise and efficient use of our resource particularly the financial resource is crucial. This study revealed that HZOFED had inefficient budget utilization. The approved budget was not consumed as the plan in each woreda finance office. Therefore, finance firms should develop and capacitate finance workers to utilize as the pre-planned tasks and had better improve the execution budget implementation squarely as the plan developed.

\section{$>$ Establishing Budget Control System in Finance Sectors}

Budget controlling is one of the key managerial functions that check how much the firm's plans and goals have been done properly. Without controlling budget, decision making is impossible. Controlling is done through established criteria to ensure the effectiveness of the sectors' plan so as to improve the performance.

\section{$>$ Maintaining consistencies of tax revenues budget}

Tax revenues budget is the back bone for sustainable economic development and growth. An objective of a tax revenue budget is to finance government activities, to stabilize the economy, to provide social justice through redistribution of income, wealth and to encourage investment. Therefore the finance sectors should support the consistence to meet the goals of revenues, the logistics and inputs to facilitate taxes.

\subsection{1: REFERENCES}

Bartle, J. (2001). Evolving Theories of Public Budgeting. JAI press

Bartle, J. (2008). Applying Pragmatism to Public Budgeting and Financial Management, Texas: State University Hildereth, K. (2002). Budget Theory in Public Sector. Qourum books

Hirst, M. (1987). the Effects of Setting Budget Goals and Task Uncertainty on Performance: A Theoretical Analysis. The Accounting Review, 62(4), 774-784.

Horngren, C.T (1999). Management Accounting, 11th edition USA.

Jess Burk Head (1965), Government Budgeting; John Wiley and Sons, Inc. New York.

Joshi, P.L., Al-Mudhaki, J., \& Bremser, W.G. (2003). Corporate Budge Planning, Control and Performance Evaluation in Bahrain, in: Managerial Auditing Journal, Vol. 18(9), pp. 737-750.

Kariuki (2010).Budgeting: A fundamental management tool.

Lucey, T. (2002).Costing, 6th Edition, Great Britain Continuum, London

MOFED. (2009). Financial Transparency \& Accountability: Laypersons Budget and Expenditure Templates. Addis Ababa.

Nice David C... (2002) Public Budgeting wads worth/ Thomson learning (Belmont CA)

Premachand A. (1995) Effective Government Accounting Washington D.C International Monetary Fund

Schiavo- Campo, Salvatore and Tommasi, Daniel. (1999). Managing Government Expenditure. Manila, Philippines: Asian Development Bank.

Shields, M.D., and Young, M.S., "Antecedents and consequences of participative budgeting: Evidence on the effects of asymmetrical information", Journal of Management Accounting Research, (1993), 5, 265

Thomas, H. (2000). Power in the resource allocation process; the impact of rational systems; Journal of Higher Education Policy and Management, 22, 127-137

Ugwuanyi, U. B., and Ebe, E. C. (2012).Impact of Poor Accounting Practices on Budget Implementation of Government owned Industries. A Study of Enugu State. Research Journal of Finance and Accounting, 3(11), 8-15. 